Please do not remove this page

RMIT

UNIVERSITY

\title{
Drug-related police encounters across the globe: How do they compare?
}

Hughes, Caitlin; Barratt, Monica; Ferris, Jason; Maier, Larissa; Winstock, Adam

https://researchrepository.rmit.edu.au/esploro/outputs/9921861027801341/filesAndLinks?institution=61RMIT_INST\&index=null

Hughes, C., Barratt, M., Ferris, J., Maier, L., \& Winstock, A. (2018). Drug-related police encounters across the globe: How do they compare? International Journal of Drug Policy, 56, 197-207.

https://doi.org/10.1016/j.drugpo.2018.03.005

Document Version: Accepted Manuscript

Published Version: https://doi.org/10.1016/j.drugpo.2018.03.005

Repository homepage: https://researchrepository.rmit.edu.au

CC BY-NC-ND V4.0

(C) 2018 Elsevier B.V. All rights reserved.

Downloaded On 2023/04/26 23:07:36 +1000

Please do not remove this page 


\title{
Title: Drug-related police encounters across the globe: How do they compare?
}

\author{
Dr Caitlin E Hughes ${ }^{1}$, Dr Monica J Barratt ${ }^{123}$, Associate Professor Jason A Ferris ${ }^{4}$, Dr Larissa J \\ Maier $^{5}$, Professor Adam R Winstock ${ }^{67}$ \\ ${ }_{1}^{1}$ Drug Policy Modelling Program, National Drug and Alcohol Research Centre, UNSW, Sydney, NSW, Australia \\ ${ }^{2}$ National Drug Research Institute, Faculty of Health Sciences, Curtin University, Perth, WA, Australia. \\ ${ }^{3}$ Behaviours and Health Risks Program, Burnet Institute, Melbourne, VIC, Australia. \\ ${ }^{4}$ Institute for Social Science Research, The University of Queensland, St Lucia, QLD, Australia. \\ ${ }^{5}$ University of Zurich, Zurich, Switzerland. \\ ${ }^{6}$ Institute of Epidemiology \& Health Care, Faculty of Population Health Sciences, University College London. \\ ${ }^{7}$ Global Drug Survey Ltd, London, UK. \\ A submission to the IJDP Special Issue on Comparing Drug Policies
}

\section{Abstract}

Background: Drug law enforcement subsumes the majority of drug policy expenditure across the globe. Fuelled by knowledge that much of this investment is ineffective or counter-productive there have been increasing calls for cross-national comparisons to identify where policing approaches differ and what types of approaches may be more effective. Yet, to date cross-national comparison of drug law enforcement has proven a methodologically hazardous affair. Using a new drug policing module added to the 2017 Global Drug Survey, this study seeks to provide the first cross-national comparison of the incidence, nature and intensity of illicit drug-related police encounters amongst people who use drugs.

Methods: The Global Drug Survey was administered in late 2016. Across 26 countries including Australia, Germany, Italy, Mexico, Switzerland, the UK and the USA a total of 45,942 people who had recently used drugs completed the drug policing module. Key variables assessed included the incidence and frequency of drug-related police encounters in the last 12 months that involved: a) being stopped and searched; b) encountering a drug detection dog; $c$ ) being given a caution or warning; d) being charged and arrested; and e) paying a bribe. Multi-level models were used to control for pre-existing national differences in drug use prevalence and non-drug specific policing (including the total number of police personnel in each country).

Results: Drug-related police encounters were most commonly reported in Italy and Scotland. Conversely, police encounters were most likely to lead to arrest in Norway, Finland and Sweden. The type and locations of encounters further differed across countries, with for example stop and search most reported in Greece and Colombia, and encounters with drug detection dogs most reported in Scotland, Italy, UK and Australia. Multi-level models showed that the incidence of reported policing encounters continued to differ significantly across countries after controlling for pre-existing national differences in drug use prevalence and policing, and that drug policing encounters were 4 to 14 times more common in some nations than others.

Conclusion: The findings unearth significant cross-national differences in the incidence and nature of drug-related policing of people who use drugs. This suggests that there may be opportunities for countries to learn from each other about how and why they differ, and the potential benefits of switching to lower intensity modes of drug policing. 
Key words: Policing; Arrest; Stop and Search; Drug detection dog; Comparative policy analysis; Cross-national comparison. 


\section{Introduction}

Drug law enforcement subsumes the majority of drug policy expenditure across the globe (Babor et al., 2010; Ritter, Hughes, \& Hull, 2016a; Ritter, McLeod, \& Shanahan, 2013; Ritter \& Stevens, 2017). For example, $64 \%$ of Australian government expenditure on illicit drugs is directed at policing and enforcing laws (Ritter et al., 2013) and in the USA, UK and Sweden, 59\%, 65\% and $75 \%$ of government expenditure respectively is directed at this domain (Ritter et al., 2016a). But research has shown that much of this investment does not achieve its intended goals: and indeed that investment is making the problem worse (Babor et al., 2010). For example, street-level drug law enforcement has minimal capacity to deter drug use or supply (Hughes, Moxham-Hall, Ritter, Weatherburn, \& MacCoun, 2017a). Equally, studies from across the globe, including the USA, UK, Australia, Russia, Mexico, Thailand, and Canada have shown that criminal justice responses have typically targeted people who use drugs not drug traffickers (Babor et al., 2010; Caulkins \& Reuter, 2016; McDonald \& Hughes, 2017a), which has encouraged high risk drug use practices such as rapid or unsafe injecting (Aitken, Moore, Higgs, Kelsall, \& Kerger, 2002; Hayashi, Small, Csete, Hattirat, \& Kerr, 2013; Maher \& Dixon, 1999; Sarang, Rhodes, Sheon, \& Page, 2010), limited access to harm reduction and healthcare services (Kerr, Small, \& Wood, 2005), and increased overdoses and HIV/AIDS (Csete, 2007; Csete et al., 2016; Kerr et al., 2005). Furthermore, as evidenced by studies from Mexico and Russia, specific policing practices can lead to added harms, including unlawful arrests of people who inject drugs (PWID) for syringe possession (in spite of laws permitting carrying of injecting equipment), physical and sexual violence and police corruption and bribery (requiring people who use drugs to pay money to avoid arrest and/or jail) (Lunze et al., 2014; Miller et al., 2008; Sarang et al., 2010; Volkmann et al., 2011; Wood et al., 2017). The large investment but growing evidence of harms has spurred increasing calls for cross-national comparison of drug law enforcement approaches: to learn about where policing approaches differ and what types of approaches may be more effective (Kilmer, Reuter, \& Giommoni, 2015; Reuter, 2017).

As outlined by Ritter et al. (2016b) and Burris et al. (2017) comparative policy analysis or crossnational comparisons in the illicit drug policy arena can be a very valuable method to unearth differences (and similarities) in approaches, as well as to show why these have emerged and the worth of different approaches. Variations in countries' legal approaches to drugs are well documented, including what psychoactive substances countries prohibit, the chosen model for responding to psychoactive substances - particularly whether countries criminalise, decriminalise or legalise and regulate drugs, as well as the penalty regimes and legal threshold limits for possession for 'personal use' versus 'supply' (Babor et al., 2010; Belackova, Ritter, Shanahan, \& Hughes, 2017; Chapman, Spetz, Lin, Chan, \& Schmidt, 2016; Kilmer \& Pacula, 2016; Klieger et al., 2017; Pacula, Powell, Heaton, \& Sevigny, 2015; Ritter et al., 2016a). Each regulatory component can impact on the extent and nature of harms to people who use drugs as well as the broader community. For example, there are now more than 25 countries that have introduced some form of drug decriminalisation (or the removal of criminal penalties) (Rosmarin \& Eastwood, 2013). Compared to criminalisation of illicit drug use and possession, decriminalisation (or the removal of criminal penalties) can lead to 
significant social, health and criminal justice benefits such as reducing imprisonment, overdose and drug-related HIV (Babor et al., 2010; Belackova et al., 2017; Hughes \& Stevens, 2010; Massin, Carrieri, \& Roux, 2017; Single, Christie, \& Ali, 1999; Stevens \& Hughes, 2016). Moreover, Pacula et al. (2015) mapped the variation in medical cannabis laws across the USA, showing that some schemes were associated with more adverse outcomes. Of note, those that employed legal protections for dispensaries were associated with much more recreational cannabis "use and abuse" among adults (Pacula et al., 2015). Yet, while there has been a lot of attention paid to comparing drug laws across nations, there has been negligible attention to comparing drug law enforcement. This is a significant omission. For example, as argued by Kilmer, Reuter, and Giommoni (2015, p. 279) "focusing on drug law enforcement is much more important for cross-national drug policy comparisons than focusing on drug laws." This is particularly as leading scholars now argue that one of the biggest determinants of drug-related harm is not laws, but the intensity and severity of drug law enforcement (Caulkins \& Reuter, 2009; Caulkins \& Reuter, 2016; Kleiman, 2010).

Stumbling blocks to cross-national comparative research of drug law enforcement have been both methodological and conceptual (Kilmer et al., 2015). First, it is much harder to assess what police do, than to assess laws which are written or recorded in laws, regulations and guidelines (Wagenaar \& Burris, 2013). This is particularly true in relation to illicit drugs (McDonald \& Hughes, 2017b). Second, the available metrics of drug law enforcement such as on "arrest" are seldom directly comparable across countries due to marked differences in reporting and recording practices (Kilmer et al., 2015). Third, there are no current metrics on any form of pre-arrest activity or different types of policing responses e.g. warning versus stop and search. This is vital data to measure the overall frequency and intensity of policing approaches, as well as the punitiveness (defined as the likelihood of stops converting to an arrest) and to improving assessments of drug law enforcement across the globe (Kilmer et al., 2015). Police culture and police organisational performance metrics can further affect agencies willingness to attend to research evidence and/or new drug policing approaches (Bear, 2016). This is particularly in a climate of continuing popularity of law and order politics (Weatherburn, 2004) and the new punitiveness of crime control (Pratt, Brown, Brown, Hallsworth, \& Morrison, 2013), which directly or indirectly incentivise traditional crime control policing approaches.

One recommendation of Kilmer et al (2015) for gathering comparable cross-national drug law enforcement data, is through capitalising upon existing cross-national surveys. This can ensure that the same set of metrics can be employed in all nations: thereby eliminating incompatibility and capturing multiple indices of drug-related policing encounters (pre-arrest and arrest). Herein we employ this approach. Using a new drug policing module added to the 2017 Global Drug Survey, this study seeks to provide the first cross-national comparison of the incidence, nature and punitiveness of illicit drug-related police encounters amongst people who use drugs.

Specifically, the aims are: 
1. To compare the incidence, nature and punitiveness of drug-related police encounters amongst people who use drugs across multiple countries

2. To identify which countries, have the highest (and least) intense and punitive policing responses, after controlling for pre-existing individual and national differences in policing and drug use prevalence

Controlling for pre-existing individual and national differences is important as within country studies have shown a number of factors that shape the likelihood of being policed for drugs. The first such factor is ethnicity. For example, Mitchell and Caudy (2015) found that at age 22, African-Americans had $83 \%$ greater odds of a drug arrest than whites, and at age 27 African-Americans had $235 \%$ greater odds of a drug arrest than whites. Moreover, analysis of official statistics provided by the Ministry of Justice and the Metropolitan Police Service for 2009/10 by Eastwood, Shiner and Bear (2013) showed that black people in the UK were 6.3 times more likely to be stopped and searched for drugs than white people. Other factors that can shape the likelihood of being policed for drugs are sex, employment status and criminal justice history. For example, Koch et al. (2016) found US males were 2.4 times more likely to be arrested for drug use and possession, and that those who were unemployed and those with prior histories of incarceration were 1.6 and 6.4 times respectively more likely to be arrested. Moreover, through analysis of 12 years of sanctions for possession of drugs for personal use in Denmark, Houborg et al (2016) showed that males, young people, unemployed, and those with prior criminal records were most likely to be arrested and sanctioned for this offence.

Criminological studies have further shown how regional differences can affect policing experiences, and if not controlled for may lead to erroneous conclusions being drawn (Gelman, Fagan, \& Kiss, 2007; Levchak, 2017; Ross, 2015). For example Gelman et al (2007) and Levchak (2017) examined the extent of racial bias in the New York City Police Department's stop and frisk policy. Using multilevel logistic models Levchak showed that precinct-level differences accounted for some apparent racial bias as the percent of blacks and Latinos in a precinct increase the odds of being frisked, and the percent of Latinos in a precinct increases the odds of being subject to the use of force. Importantly, Levchak (2017) also showed that after controlling for precinct-level differences the odds of being frisked or having force used remained greater for blacks and Latinos, thus indicating that there were 'real' racial disparities in New York City Police Department's stop and frisk policy. In relation to drugs policing specifically we conjecture that there are two national factors that warrant controlling for. First, drug use prevalence, which will affect the propensity to offend (United Nations Office on Drugs and Crime, 2017b), and second, the overall level of non-drug specific policing within a country (Bushnell, 2017) which is likely to affect the likelihood of encountering police (irrespective of whether for drugs or something else). Herein we assess drug policing encounters and control for both individual and national level factors. 


\section{Methods}

The data source: 2017 Global Drug Survey

The data for this analysis were drawn from the 2017 Global Drug Survey. The Global Drug Survey (GDS) is the world's largest anonymous, annual web survey of psychoactive substance use: and has now been running for six years (see Barratt et al., 2017 for an overview). The survey is widely promoted through global news and media partner websites, social media networks such as Facebook and Twitter, and harm reduction agencies. All participants are self-selected, and all data are selfreported, hence, the results are not representative of the wider drug using population. But, the survey provides a mechanism to recruit large numbers of otherwise hard-to-reach groups across multiple countries (Barratt et al., 2017). The value of the data borne from the survey is broad with over 25 peer-reviewed publication published using GDS data since 2013 (see for example Barratt, Ferris, \& Winstock, 2014; Barratt et al., 2017; Labhart, Ferris, Winstock, \& Kuntsche, 2017; Morley, Lynskey, Moran, Borschmann, \& Winstock, 2015; Winstock, Griffiths, \& Stewart, 2001), including for crossnational comparisons of the nature and impacts of different alcohol policies (Labhart et al., 2017).

The Global Drug Survey 2017 (GDS2017) ran from November 2016 to December 2016 and was open to anyone aged 16 and over who consented to participate. The survey included core modules on patterns of use of alcohol, tobacco, illicit drugs, pharmaceuticals, and new psychoactive substances as well as new modules on cannabis legalisation, vaping, and drug policing. To increase global reach the survey was translated into ten languages: English, German, French, Dutch, Italian, Portuguese, Danish, Spanish, Swedish and Hungarian. Ethics approval for this analysis was obtained by the King's College London Psychiatry, Nursing and Midwifery Research Ethics Subcommittee (PNM/14/15-18), the University of New South Wales Human Research Advisory Panel (HC17752) and the University of Queensland (2017001452/11671/001).

\section{The sample for this analysis}

The GDS2017 received 119,729 responses from 211 countries. For this analysis, three inclusion criteria were applied, specifically that all participants 1) reported use of any illicit drug in the last 12 months, 2) had completed the drug policing module (defined as providing a valid answer to the question about whether they had encountered police for any reason in the last 12 months) and 3) were aged 18 and over. This left a sample of 47,734 respondents from 153 countries. Further, as the focus of this analysis was cross-country comparisons, countries with a minimum of 200 respondents were retained for analysis. Three respondents were excluded due to invalid responses. This left a final sample of 45,942 respondents from 26 countries. Compared to the final sample, most of the countries excluded contained a similar or lower reported incidence of drug-related policing encounters. Exceptions to this were Bosnia and Herzegovina, Serbia and Montenegro, and Russia where $27.9-42.9 \%$ respondents reported drug-related police encounters in the last 12 months.

\section{$\underline{\text { Measures }}$}


Key variables assessed in the drug policing module were the incidence and frequency of any policing encounter in the last 12 months and the incidence and frequency of drug-related police encounters in the last 12 months that involved: a) being stopped and searched; b) encountering a drug detection dog; c) being given a caution or warning; d) being fined; e) being charged and arrested; and f) paying a bribe. Definitions of each are below:

- Police encounter: Where you saw police at an event or location you were attending. For example, police patrolling at a music festival. The police were present and visible but took no active action against you or they stopped you, searched you, cautioned you or arrested you.

- Police encounters with drug detection dogs: Where you encountered police with dogs specifically trained to detect illicit drugs, also known as "sniffer" dogs at any setting excluding airports (e.g. at a pub).

- Stop and search: Where police actively stopped you in relation to drugs or drug offences, questioned you or searched you or your belongings.

- Caution or warning: Where police issued you an "on the street" caution (sometimes referred to as a warning) instead of arresting you. In some instances, the caution may have involved an optional referral to drug education or treatment.

- Fine: Where police issued you a fine (or civil penalty) instead of arresting you for drugs.

- Arrest: Where you were arrested for drug offences.

- Police bribe: Where you offered money to the police to avoid or lessen a drug charge.

The design of the drugs policing module was informed by prior Australian surveys and assessments of street-level drug law enforcement encounters (Belackova et al., 2017; Hughes et al., 2017a; Hughes \& Moxham-Hall, 2017; Shanahan, Hughes, \& McSweeney, 2017), as well as additional international expert input from the GDS team and international advisors. The module was also piloted prior to launch.

A range of demographic, drug use and offending information were also collected. Variables included: country, rurality/regionality, age, sex, sexual orientation, ethnicity, education, employment, the frequency of clubbing and the last 12 months prevalence and frequency of illicit drug use, by type.

Finally, five variables were used to control for country level variation (three of different types of drug use prevalence and two of policing):

- The last 12-month prevalence of cannabis use, prevalence of cocaine use, and prevalence of "ecstasy" type substances use in each country amongst the population aged 15-64. These measures provided a means to adjust for national differences in the three most used substances amongst the GDS2017 population. Each dataset was sourced from the United Nations Office on Drugs and Crime (UNODC) country profiles (2017a) using the most recent data available (ranging from 2011 to 2016). 
- The number of police personnel per 100,000 population in each country, defined as the number of personnel in public agencies whose principal functions was the prevention, detection and investigation of crime and the apprehension of alleged offenders. This dataset was sourced from the UNODC country profiles (2017a): derived from the annual United Nations Survey on Crime Trends and Operations of Criminal Justice Systems, for 2013 specifically.

- The aggregate incidence of any police encounters in the last 12 months in each country. This dataset was sourced from the GDS2017 drug policing module by aggregating the proportion of GDS respondents in each country that reported encountering police for any reason in the last 12 months.

There are well acknowledged challenges in cross-national comparison particularly for examining data that has been pre-collected: including different years or methods of data collection and different definitions such as of 'police personnel' (Giommoni, Reuter, \& Kilmer, 2017; Kilmer et al., 2015; Ritter et al., 2016b). That said, the UNODC is the most reputed source of global data on drug use and criminal justice systems and the only data source covering all countries included in this analysis (Stamatel, 2006). As such, it offered the best means to account for some national differences. Our final variable, having been collected within the survey, was more comparable, albeit this was important to supplement with other country-level controls.

\section{Analysis}

Pearson's chi square test for categorical variables was used to examine the unadjusted cross-national incidence and punitiveness of drug policing encounters (defined as the proportion of encounters in the last 12 months that lead to an arrest) to identify 1 ) whether there were any significant differences in the reported incidence and punitiveness of encounters across countries, and 2) which countries had the most (and least) intense and punitive policing responses. Multi-level logistic regressions were then constructed to control for individual level factors and country level factors that may impact upon the likelihood of a drug policing encounter across countries. Specifically, the first model controlled for individual level factors alone (e.g. such as age and ethnicity) and the second model controlled for individual-level and country-level factors (the five points above). The multi-level model was then used to re-calculate the probability of a drug policing encounter and of an encounter that would lead to arrest across the 26 countries, after accounting for individual and country level differences. 


\section{Results}

\section{The GDS drug policing sample}

The GDS sample for this analysis $(n=45,942)$ was predominantly young (mean=28.6, $S D=10.5)$, white/Caucasian (89.4\%) and male (71.9\%) (see supplementary Table S1 for full details). Most lived in city/urban areas (73.3\%), albeit a substantial minority lived in regional areas (23.0\%). The sample was well educated - with $61.8 \%$ having post secondary school qualitifications (e.g. a degree or certificate) and $63.4 \%$ in full or part-time employment. The majority $(78.4 \%)$ of the sample went clubbing: albeit there was a mixture of low and high frequency clubbers. By definition, all respondents were people who had used illicit drugs in the last 12 months. The most commonly used drugs over this period were cannabis $(91.3 \%)$, ecstasy $(37.5 \%)$, and cocaine $(20.3 \%)$. With the exception of cannabis (median=60 days) the sample reported a low median frequency of cocaine or ecstasy use 2 to 4 days in the last 12 months.

Table 1 presents the number of respondents from the 26 countries used in the cross-national analysis, and the country level factors for each sourced from the UNODC and the GDS. Of note, the sample included respondents from four continents - Europe, USA/Canada, Central/South America and Australasia. The countries also had quite different prevalence of use and policing characteristics (see Table 1), which we control for in the final section of the analysis (Table 4).

\section{**** Insert Table 1 about here $* * * *$}

\section{Incidence of any recent drug-related police encounter across the 26 countries}

On average $32.4 \%$ of respondents reported any form of police encounter in the last 12 months, and $15.8 \%$ reported any form of drug-related policing encounter - defined as any police encounter in relation to their drug use, irrespective of type. Across the 26 countries, the incidence of a recent drug policing encounter ranged from $6.0 \%$ to $32.0 \%$ (see Figure 1), a statistically significant difference $\left(X^{2}(25)=1834.07, p<0.001\right)$. The countries with the highest reported incidence were Italy, Norway, UK, Australia and Colombia. On the other hand, countries with the lowest reported incidence were Austria, New Zealand and the Netherlands.

\section{${ }^{\star \star \star \star}$ Insert Figure 1 about here ${ }^{* \star \star \star}$}




\section{Nature of drug policing encounters}

There were further significant differences in the type of drug policing encountered across the countries (see Table 2). For example, on average 9.4\% all respondents reported they encountered a drug detection dog in the last 12 months, but this ranged from $1.5 \%$ to $27.4 \%$ across the countries $\left(X^{2}(25)=3653.58, p<0.001\right)$. Consequently, respondents from Italy, UK and Australia were 5-6 times more likely to report drug dog encounters in the last 12 months than those in Austria, Netherlands, Germany and New Zealand. Moreover, while on average $8.0 \%$ respondents reported they were stopped and searched for drugs by the police, this was rarely reported in the Netherlands and Australia (reported by $4.0 \%$ respondents), but was more common in Poland, Colombia and France (reported by $15.6-17.4 \%$ respondents) $\left(X^{2}(25)=511.311, p<0.001\right)$. The offer of money/bribes to police was rare in most countries $(0.4 \%)$, but it was more common in Colombia and Mexico where $9.0 \%$ and $7.4 \%$ respondents reported offering money to police and $8.8 \%$ and $7.4 \%$ respectively reported the money was accepted by police $\left(X^{2}(25)=1948.23, p<0.000\right)$. Finally, while $\leq 0.5 \%$ respondents in Portugal, the Netherlands and New Zealand reported being arrested for drugs in the last 12 months, this was much more common in Norway, where $5.6 \%$ respondents reported being arrested $\left(X^{2}(25)=290.33, p<0.000\right)$.

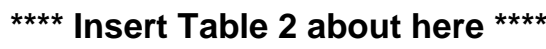

As exemplified in relation to police encounters for drug detection dogs, there were further significant differences in where police were encountered. For example, as shown in Table 3 while the most common site of encountering drug dogs was a festival (58.7\%), followed by public transport $(41.6 \%)$ and clubs/pubs (16.8\%), there were significant variations in the reported cross-country incidence of encounters across all three settings $\left(X^{2}(25)=2746.21, p<0.001 ; X^{2}(25)=2059.96, p<0.001\right.$, and $X^{2}(25)=2075.28, p<0.001$ respectively). For example, drug dog encounters at pubs and clubs were commonly reported in Australia and the UK (reported by $35.9 \%$ and $34.0 \%$ respondents respectively), but there were no reported encounters at this setting in Greece or Ireland. Moreover, while on average only $3.0 \%$ respondents reported drug dog encounters at residential premises, respondents from some countries reported high incidence of encounters at such settings e.g. Norway and Finland $\left(16.7 \%\right.$ and $12.0 \%$ respectively) $\left(X^{2}(25)=249.19, p<0.001\right)$. Moreover, respondents from some countries reported very high rates at "other" premises - particularly schools or universities e.g. New Zealand, Greece and Colombia (29.3\%-35.4\%) $\left(\left(X^{2}(25)=414.03, p<0.001\right)\right.$. Comparing the set of venues showed that in some countries almost all drug dog encounters were at festivals e.g. Netherlands and Hungary, whilst for other countries including Australia, Scotland and the UK encounters occurred across multiple settings.

\section{**** Insert Table 3 about here $* * * \star$}




\section{Punitiveness of drug policing encounters}

Finally, examining the punitiveness of drug-related police encounters shows that on average $7.7 \%$ of drug-related encounters ended in arrest. But again this varied across countries from 1.6-2.2\% in Italy, the Netherlands and Portugal to $19.4-20.7 \%$ in Finland and Norway: a 9-12 fold difference $\left(X^{2}(25)=81.481, p<0.001\right)$. That said, once we map the confidence bounds (Figure 2$)$ here we can see a high level of overlap across countries.

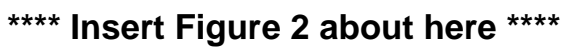

\section{Cross-national differences in drug policing, controlling for individual and country level effects}

As highlighted in Table 1 (see also supplementary Figure S1) there were large differences across countries in drug use prevalence and policing. For example, across the 26 countries, Italy, Greece and Portugal had the highest rates of police personnel per 100,000 population, and Hungary and Finland the lowest rate. In this final section we use multi-level models to control for individual and country level variables to see whether the observed differences in drug policing remain.

As outlined in Table 5 (Model 1b) a number of individual level factors shape the probability of a drug policing encounter in the last 12 months: sex, age, age2 (or age squared which tests whether the impact of age is non-linear and hence differs across the lifespan), residence, ethnicity, education, employment, clubbing frequency and whether or not an individual has prior policing encounters. Being male (1.6), of regional residence (defined as living on the outskirts of cities or urban areas) (1.2), clubbing frequently i.e. 4 or more times a year (1.3), being in paid employment (1.3) or unemployed but looking for work (1.8) and having prior police encounters (1.0) all increased the likelihood of a drug policing encounter. Conversely, having a white/caucasian ethnicity reduced the likelihood of a drug policing encounter (0.8). Finally, age and age2 both affected the likelihood of a drug policing encounter, which meant that the impact of age on police encounters changed over the lifespan. Specifically, being aged 18 to 20 increased the likelihood of a drug policing encounter 2.8 to 2.9 fold, and being aged 21 to 32 increased the likelihood by a lesser degree (1.1 to 2.5 fold), but being aged over 32 reduced the likelihood of a drug policing encounter 0.2 to 0.8 fold.

Four national factors (Model 1c) also shaped the probability of a drug policing encounter in the last 12 months. Specifically, regarding national drug use factors, Table 5 shows that having a higher national prevalence of cocaine use within a country (1.4) increased the likelihood of a drug policing encounter, but having a higher national prevalence of cannabis use reduced the likelihood of drug policing encounters (0.9). The national prevalence of ecstasy use had no significant impact on the probability of a drug policing encounter. In relation to national policing factors, a higher total police personnel per 100,000 population (1.0) and higher aggregate incidence of encountering police (1.0) both increased the likelihood of drug policing encounters. 


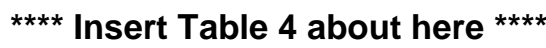

Importantly, as shown in Figures 3, 4a and $4 \mathrm{~b}$ taking into account the individual and national factors, significant country differences remain in the probability of drug policing encounters. For example, the probability of any drug policing encounter remained 4.8 times more common in some countries than others. Specifically, the countries with the highest probabilities of a drug policing encounter in the last 12 months were Italy $(0.350, \mathrm{Cl}=0.3120-0.388)$ and Scotland (0.312, $\mathrm{Cl}=0.278-0.347)$. Conversely, the countries with the lowest probabilities of a drug policing encounter in the last 12 months were New Zealand (0.064, $\mathrm{Cl}=0.041-0.087)$, Austria (0.091, $\mathrm{Cl}=0.078-0.105)$, Germany (0.094, $\mathrm{Cl}=0.081-0.107)$, Switzerland (0.097, $\mathrm{Cl}=0.081-0.113)$ and Brazil $(0.101, \mathrm{Cl}=0.083-0.121)$.

Concerning drug detection dogs Figure 4a shows even more cross-country variation: between 0.309 $(\mathrm{Cl}=0.266-0.353)$ and $0.022(\mathrm{Cl}=0.018-0.026)$. As such after controlling for individual and national factors, encounters with drug detection dogs were up to 14 times more common in Italy, Scotland, UK and Australia than in Austria, Germany, Brazil and New Zealand. Furthermore, Figure $4 \mathrm{~b}$ shows that there continued to be significant variation in the incidence of stop and search: between 0.143 $(\mathrm{Cl}=0.12-0.165)$ and $0.032(\mathrm{Cl}=0.161-0.048)$. As such, the incidence of police stop and searches for drugs was up to 4.4 times higher in Colombia, Italy, Greece and Sweden than in New Zealand and Australia. In contrast, after adjusting for individual and national level factors, there was no significant variation between countries in their punitiveness of drug policing. As shown in Figure 4c Brazil and the USA were the most punitive countries and Australia the least punitive, but there was almost complete overlap in their confidence bounds.

\section{${ }^{\star \star * \star}$ Insert Figure 3 and Figures $4 a, 4 b$ and $4 c$ about here ${ }^{* \star * *}$}

\section{Discussion}

This study sought to provide the first cross-national insights into the incidence, nature and punitiveness of drug-related policing encounters amongst people who use drugs, using a purposebuilt drug policing module in the 2017 Global Drug Survey. By administering the module across 26 different countries it has shown that drug-related policing encounters were significantly more common in some countries than others and that the types of policing encountered and locations where encounters occurred further differed. Individual and national differences account for some such differences: particularly ethnicity, age, sex, and frequency of clubbing, and the national prevalence of cannabis and cocaine use and the number of police personnel in a country. But, importantly, after controlling for such differences, significant cross-national differences in the incidence of drug policing remain. As such we can now conclude that of the 26 countries examined Italy and Scotland are the countries with the most intense drug policing, and New Zealand, Austria, Germany, Switzerland and Brazil the countries with the least intense drug policing. That said, contrary to expectations, we found 
no significant cross-national differences in the punitiveness of drug-related policing encounters (that is the extent to which an encounter led to arrest).

Limitations with this study need to be acknowledged. First, the sample was derived online, which tends to favour recruitment of more educated populations of people who use drugs (Miller \& Sønderlund, 2010). By excluding disadvantaged populations, who are often a target for drug policing, it may provide a conservative measure of the incidence of drug-related policing encounters in each country. Second, all data were obtained via self-report which can suffer from memory errors or social desirability errors (Harrison, 1995; Krumpal, 2013). That said, we have no reason to suspect people would deliberately lie on a survey about these issues, especially in an anonymous web survey which has a lower 'social desirability' bias, and in a survey for which there were no financial inducements offered (Krumpal, 2013). Moreover, cognisant of the risk of memory errors, we focused this analysis on the incidence, nature and location of encounters (rather than on the other metric that we collected - the frequency of encounters - which may be more prone to memory errors). Third, the country-level indicators from the UNODC referred to the year 2013 for police personnel estimates and 2011 to 2016 for drug use prevalence. Any changes in prevalence or police personnel before 2016 may have impacted on estimates of the reported incidence of drug policing encounters. Limitations aside, as the first cross-national study of drug policing, this study has important contributions for research and policy.

This study adds to the well-documented variations in drug laws across the globe (Babor et al., 2010; Belackova et al., 2017; Chapman et al., 2016; Kilmer \& Pacula, 2016; Klieger et al., 2017; Pacula et al., 2015; Ritter et al., 2016a), by highlighting the significant cross-national differences in policing experiences for people who use drugs in terms of the likelihood of encountering police for drugs, as well as the locations and the methods of being policed. That there are differences in policing even within countries that have decriminalised drug use and possession (see for example, the Netherlands and Portugal with low incidence of drug policing versus Italy with very high incidence of drug policing) suggests that as conjectured what police do may matter much more for on the ground experiences than what the drug laws state (Caulkins \& Reuter, 2009; Caulkins \& Reuter, 2016; Kleiman, 1992; Kleiman, 2010).

Consistent with Ritter et al. (2016b) and Burris et al. (2017) and the argued benefits of a crossnational or comparative approach this study starts to illuminate key differences in drugs policing across the globe. The first, and most important difference concerns the intensity of drugs policing. That there is a 14-fold difference in the probability of some drug policing encounters suggests that as conjectured there may be a real divide between countries with "low intensity", "moderate intensity", and "high intensity" policing approaches. Moreover, coupled with the finding that there were no significant differences in the likelihood of an encounter leading to arrest across the 26 countries suggest high intensity approaches may be unnecessary. This matters as extant literature shows that high intensity approaches often come at significant costs to communities (Caulkins \& Reuter, 2016; Kleiman, 2010). For example, Gould and Mastrofski (2004) found that $59.9 \%$ of US police searches were unconstitutional when they related to drugs, and contribute to costs to police in terms of 
opportunity costs of not policing more serious crime, and loss of legitimacy of police institutions, as well as cost to people who use drugs and their communities of discrimination, stigmatisation and disenfranchisement. The second difference is the method of policing. The present study shows that there can be quite distinct approaches to policing even amongst countries with "higher intensity" policing encounters, including on the one hand Greece, Sweden, Denmark, Belgium, and Poland with high incidence of stop and search for drugs (albeit not high incidence of drug detection dog encounters), and on the other hand Scotland, UK, Australia and Norway with high incidence of drug detection dogs (albeit not high incidence of stop and search). This finding is again important, as research shows the modes of policing can vary in terms of costs, their capacity to deter or prevent use as well as risks of adverse outcomes. Of particular note, we highlight the risks of drug dogs which have been shown to increase consumption of drugs on site of dogs - a clear risk for overdose - as well as incentivising consumption of less detectable but sometimes more harmful drugs (such as 'ecstasy' or methamphetamine instead of cannabis) (NSW Ombudsman, 2004; Hickey et al, 2012). Third, the finding that there are significant cross-national differences in the location of policing again matters - particularly in whether they focus on known sites of use versus broader settings. For example, extant literature shows that while policing at festivals and clubs can increase harmful behaviour such as hasty consumption or incentivising people to buy drugs when out rather than carry drugs into festival grounds, there can also be public health and safety benefits from policing such settings (Hughes et al, 2017). In contrast, policing at homes and workplaces raise significant human right issues, including incursions to rights to privacy and stigma and discrimination of people who use drugs, for scant public health or safety gains (Gould \& Mastrofski, 2004).

Finally, this analysis brings to light factors that shape or may shape the frequency and nature of drug policing encounters. This includes national prevalence of drug use and national policing approach - a finding that is consistent with the studies of Gelman et al (2007) and Levchak (2017). Also important are regional differences e.g. Nordic more punitive (Bjerge, Houborg, Edman, \& Perälä, 2016), and South America with more corruption (albeit we also note that this was evident in Colombia and Mexico but not Brazil). (Such a finding reinforces but also extends existing studies (Miller et al., 2008; Volkmann et al., 2011), by showing police corruption in such regions goes beyond populations who inject drugs). That said, we contend that the most important factor may be national preferences regarding policing drugs specifically: evident by comparing "like with like" countries. Here of note is the approaches of Australia and New Zealand, with Australia having one of the highest rates of drug detection dog encounters and New Zealand one of the lowest, which suggests diverging national preferences - for and against drug dog deployment (Hughes, Ritter, Lancaster, \& Hoppe, 2017b). What may account for national differences in drug policing is beyond the scope of the current analysis, but we raise two potential contributors. First is the increasing emphasis of police agencies in some parts of world on police performance measures and targets for drugs, which may incentivise higher intensity drug policing approaches (Bear, 2016; Eastwood et al., 2013; Hughes \& James, 2012; Lennon \& Murray, 2016). For example, Lennon and Murry (2016) showed that in spite of similar statutory powers of stop and search the introduction of new targets facilitated a mass rise in stop and search in Scotland (and not England). Second is the attitude and beliefs of police regarding drugs- 
including the level of threat that is seen by drugs, the priorities placed upon policing people who use drugs, and beliefs about the trade-offs of such policing (Bear, 2016; Landsberg et al., 2016; Rhodes et al., 2006). Here of note is the work of Houborg et al (2016) who showed how police in Denmark were acutely aware that they could be stopping or arresting many more people for drugs, however, they chose not to, and to instead focus on building police legitimacy and policing other serious crime. This we conjecture may hold lessons for other countries.

The findings raise four implications for policy and practice. First, they show that there are significant cross-national differences in approaches to drug policing and that some countries' approaches to drug policing appear quite exceptional: particularly Scotland, Italy, UK and Australia in relation to their use of drug detection dogs, and Colombia, Italy, Greece and Sweden in relation to stop and search policies. Second, it shows that some nations that have traditionally been deemed the most punitive in relation to drugs, such as the USA, may not be the most exceptional once both pre-arrest and arrest activities are considered. This finding is consistent with the analyses of Pratt et al (2013) about crime more generally, and their calls for grounding assessments of punitiveness based on policing, as well as the actions of the courts and prison system. That said, we suggest albeit tentatively that the lower incidence of drug-related policing in the USA may be in part an artefact of timing - namely that this survey occurred post significant shifts in US drug policy, including the then legalisation of recreational cannabis use in four states, and other drug law reforms in over 26 states (Kilmer \& Pacula, 2016). Evidence to support this interpretation comes from state-level comparisons, which show significant variation in the incidence of a recent drug-related police encounter across the USA - from $4.8 \%$ to $26.1 \%$ - and that three of the states with the lowest incidence had introduced recreational cannabis legalisation: $3.8 \%$ in Alaska, $7.9 \%$ in Washington and $13.3 \%$ in Oregon (cf $18.9 \%$ in Colorado) $(\mathrm{X} 2(15)=35.479, \mathrm{p}=0.003)$.

Third, these findings remind us that countries do have choices in how they police people who use drugs and that the particular methods being deployed, even if they have persisted for some time (Hughes et al., 2017b), may not be the most effective, just or cost-effective (Babor et al., 2010; Kilmer et al., 2015; Shanahan, Hughes, McSweeney, \& Griffin, 2017). Fourth, they also indicate that there may be many opportunities for countries and regions to learn from each other about how and why they compare and the potential benefits of switching to lower intensity modes of drug policing. We are cognisant that opportunities for learning and informing drug policing debates may not be equal across the globe. This is particularly the case in non-Western nations, such as Mexico where Miller et al (2008) has showed the existence of systemic issues including low accountability and low pay scales for police officers that incentivise particular drug policing approaches including corruption as a means to supplement police incomes. In such nations lesson sharing may better aid regional efforts such of the Organisation of American States to engender evidence-informed drug policies (Organization of American States, 2013). Finally, from a methodological perspective, this study shows the importance of cross-national analyses, to provide baselines for comparison. It is only by doing so that we can start whether practices are "unique" or "normal" and to provide another lens to start to scrutinise drug policy approaches. Added to that, as conjectured by Kilmer (2015) it demonstrates the benefit of utilising existing large-scale cross-cultural surveys to capture drug law enforcement across the globe, 
and to start to bring to light the policy differences and similarities. Given the historic methodological hazards to undertaking cross-national criminal justice research this is welcome news, that could we suggest be extended to examine drug policing experiences in other countries including Russia, Thailand and other Asian countries that are perceived to have high levels of extra-judicial policing and corruption (Hayashi et al., 2013; Lunze et al., 2014), and to monitor drug policing experiences over time.

In conclusion, the analysis of the drug policing encounters across 26 countries indicates that the incidence and nature of drug-related police encounters differ significantly across countries, and that such differences remain after controlling for individual and national differences in policing and drug use prevalence. That the incidence of policing encounters was 4 to 14 times more common in some nations than others suggests that some approaches are exceptional and potentially harmful. As such, there is a clear opportunity, and indeed need, for nations to learn about how and why their national policing approaches differ, and the potential benefits of switching to lower intensity modes of drug policing.

\section{Acknowledgements}

We thank the 100000 people who see the value in completing the Global Drug Survey and the media partners (www.globaldrugsurvey.com) who help promote the survey. Thanks also to Professor Alex Stevens for assistance in question design for the drug policing module.

\section{Funding}

M.J.B. and J.A.F. were supported by fellowships from the Australian National Health and Medical Research Council (APP1070140, APP1089395). The National Drug and Alcohol Research Centre and the National Drug Research Institute were supported by funding from the Australian Government under the Substance Misuse Prevention and Service Improvement Grants Fund. This work is also supported by the contribution of the Victorian Operational Infrastructure Support Program received by the Burnet Institute.

\section{Declaration of conflicting interests}

A.R.W. is the founder and managing director of the Global Drug Survey. 


\section{References}

Aitken, C., Moore, D., Higgs, P., Kelsall, J., \& Kerger, M. (2002). The impact of a police crackdown on a street drug scene: evidence from the street. International Journal of Drug Policy, 13(3), 193202.

Babor, T. F., Caulkins, J. P., Edwards, G., Fischer, B., Foxcroft, D. R., Humphreys, K., . . Strang, J. (2010). Drug policy and the public good. Oxford: Oxford University Press.

Barratt, M. J., Ferris, J. A., \& Winstock, A. R. (2014). Use of Silk Road, the online drug marketplace, in the United Kingdom, Australia and the United States. Addiction, 109(5), 774-783.

Barratt, M. J., Ferris, J. A., Zahnow, R., Palamar, J. J., Maier, L. J., \& Winstock, A. R. (2017). Moving on from representativeness: Testing the utility of the Global Drug Survey. Substance Abuse: Research and Treatment, 2017(11), 0-0.

Bear, D. (2016). The need to create a narrative: examining the justifications police used to target drugs in the lead up to the 2011 London riots. Police Practice and Research, 17(4), 317-328. doi: $10.1080 / 15614263.2016 .1168598$

Belackova, V., Ritter, A., Shanahan, M., \& Hughes, C. E. (2017). Assessing the concordance between illicit drug laws on the books and drug law enforcement: comparison of three states on the continuum from "decriminalised" to "punitive". International Journal of Drug Policy, 41, 148157. doi: http://dx.doi.org/10.1016/j.drugpo.2016.12.013

Bjerge, B., Houborg, E., Edman, J., \& Perälä, R. (2016). Concepts and policies directed at drug use in Denmark, Finland, and Sweden. In M. Hellman, V. Berridge \& A. Mold (Eds.), Concepts of Addictive Substances and Behaviours Across Time and Place (pp. 33-56). Oxford: Oxford University Press.

Burris, S. (2017). Theory and methods in comparative drug and alcohol policy research: Response to a review of the literature. International Journal of Drug Policy, 41, 126-131.

Bushnell, A. (2017). Australia's criminal justice costs: An international comparison. Melbourne: Institute for Public Affairs.

Caulkins, J., \& Reuter, P. (2009). Towards a harm-reduction approach to enforcement. Safer Communities, 8(1), 9-23.

Caulkins, J. P., \& Reuter, P. (2016). Dealing more effectively and humanely with illegal drugs. Crime and Justice. doi: doi:10.1086/688458

Chapman, S. A., Spetz, J., Lin, J., Chan, K., \& Schmidt, L. A. (2016). Capturing heterogeneity in medical marijuana policies: A taxonomy of regulatory regimes across the United States. Substance Use \& Misuse, 51(9), 1174-1184. doi: 10.3109/10826084.2016.1160932

Csete, J. (2007). Do not cross: Policing and HIV risk faced by people who use drugs. Toronto: Canadian HIV/AIDS Legal Network.

Csete, J., Kamarulzaman, A., Kazatchkine, M., Altice, F., Balicki, M., Buxton, J., . . Beyrer, C. (2016). Public health and international drug policy. The Lancet, 387(10026), 1427-1480. doi: https://doi.org/10.1016/S0140-6736(16)00619-X

Eastwood, N., Shiner, M., \& Bear, D. (2013). The numbers in black and white: ethnic disparities in the policing and prosecution of drug offences in England and Wales London. Release Publications.

Gelman, A., Fagan, J., \& Kiss, A. (2007). An analysis of the New York city police department's "stopand-frisk" policy in the context of claims of racial bias. Journal of the American Statistical Association, 102(479), 813-823. doi: 10.1198/016214506000001040

Giommoni, L., Reuter, P., \& Kilmer, B. (2017). Exploring the perils of cross national comparisons of drug prevalence: The effect of survey modality. Drug and Alcohol Dependence.

Gould, J. B., \& Mastrofski, S. D. (2004). Suspect searches: Assessing police behaviour under the US constitution. Criminology \& Public Policy, 3(3), 315-362. doi: 10.1111/j.17459133.2004.tb00046.x

Harrison, L. D. (1995). The validity of self-reported data on drug use. Journal of Drug Issues, 25(1).

Hayashi, K., Small, W., Csete, J., Hattirat, S., \& Kerr, T. (2013). Experiences with policing among people who inject drugs in Bangkok, Thailand: A qualitative study. PLOS Medicine, 10(12), e1001570. doi: 10.1371/journal.pmed.1001570

Houborg, E., Kammersgaard, T., \& Pedersen, M. M. (2016). Drug policing in four Danish police districts. Police Practice and Research, 17(4), 329-340.

Hughes, C., \& James, S. (2012). Performance monitoring of Australian drug law enforcement agencies: Impediments to and prospects for reform. Current Issues in Criminal Justice, 23(3), 295-312.

Hughes, C. E., Moxham-Hall, V., Ritter, A., Weatherburn, D., \& MacCoun, R. (2017a). The deterrent effects of Australian street-level drug law enforcement on illicit drug offending at outdoor 
music festivals. International Journal of Drug Policy, 41, 91-100. doi:

http://dx.doi.org/10.1016/j.drugpo.2016.12.018

Hughes, C. E., \& Moxham-Hall, V. L. (2017). The Going Out In Sydney app: Evaluating the utility of a smartphone app for monitoring real-world illicit drug use and police encounters amongst festival and club goers. Substance Abuse: Research and Treatment, 11, 1-13.

Hughes, C. E., Ritter, A., Lancaster, K., \& Hoppe, R. (2017b). Understanding policy persistence - the case of police drug detection dog policy in NSW, Australia. International Journal of Drug Policy, 44, 58-68. doi: http://dx.doi.org/10.1016/i.drugpo.2017.03.007

Hughes, C. E., \& Stevens, A. (2010). What can we learn from the Portuguese decriminalisation of illicit drugs? British Journal of Criminology, 50(6), 999-1022. doi: 10.1093/bjc/azq038

Kerr, T., Small, W., \& Wood, E. (2005). The public health and social impacts of drug market enforcement: A review of the evidence. International Journal of Drug Policy, 16(4), 210-220. doi: https://doi.org/10.1016/i.drugpo.2005.04.005

Kilmer, B., \& Pacula, R. L. (2016). Understanding and learning from the diversification of cannabis supply laws. Addiction, 112(7), 1128-1135. doi: 10.1111/add.13623

Kilmer, B., Reuter, P., \& Giommoni, L. (2015). What can be learned from cross-national comparisons of data on illegal drugs? Crime and Justice, 44(1), 227-296. doi: doi:10.1086/681552

Kleiman, M. (1992). Against excess: Drug policy for results. NewYork: BasicBooks.

Kleiman, M. A. R. (2010). When brute force fails: How to have less crime and less punishment. Princeton, New York: Princeton University Press.

Klieger, S. B., Gutman, A., Allen, L., Pacula, R. L., Ibrahim, J. K., \& Burris, S. (2017). Mapping medical marijuana: State laws regulating patients, product safety, supply chains and dispensaries, 2017. Addiction.

Koch, D. W., Lee, J., \& Lee, K. (2016). Coloring the War on Drugs: Arrest disparities in black, brown, and white. Race and Social Problems, 8(4), 313-325. doi: 10.1007/s12552-016-9185-6

Krumpal, I. (2013). Determinants of social desirability bias in sensitive surveys: a literature review. Quality \& Quantity, 47(4), 2025-2047. doi: 10.1007/s11135-011-9640-9

Labhart, F., Ferris, J., Winstock, A., \& Kuntsche, E. (2017). The country-level effects of drinking, heavy drinking and drink prices on pre-drinking: An international comparison of 25 countries. Drug and Alcohol Review, n/a-n/a. doi: 10.1111/dar.12525

Landsberg, A., Kerr, T., Milloy, M.-J., Dong, H., Nguyen, P., Wood, E., \& Hayashi, K. (2016). Declining trends in exposures to harmful policing among people who inject drugs in Vancouver, Canada. Journal of the International AIDS Society, 19(4Suppl 3).

Lennon, G., \& Murray, K. (2016). Under-regulated and unaccountable? Explaining variation in stop and search rates in Scotland, England and Wales. Policing and Society, 1-18. doi: 10.1080/10439463.2016.1163359

Levchak, P. J. (2017). Do Precinct Characteristics Influence Stop-and-Frisk in New York City? A MultiLevel Analysis of Post-Stop Outcomes. Justice Quarterly, 34(3), 377-406. doi: 10.1080/07418825.2016.1162320

Lunze, K., Raj, A., Cheng, D. M., Quinn, E. K., Bridden, C., Blokhina, E., . . Samet, J. H. (2014). Punitive policing and associated substance use risks among HIV-positive people in Russia who inject drugs. Journal of the International AIDS Society, 17(1).

Maher, L., \& Dixon, D. (1999). Policing and public health: Law enforcement and harm minimization in a street-level drug market. British Journal of Criminology, 39(4), 488-512.

Massin, S., Carrieri, M. P., \& Roux, P. (2017). De jure decriminalisation of cannabis use matters: some recent trends from France. International Journal of Drug Policy, 24(6), 634-635. doi: 10.1016/j.drugpo.2013.04.008

McDonald, D., \& Hughes, C. (2017a). Chapter 9: Drug laws and regulations. In A. Ritter, T. King \& N. Lee (Eds.), Drug Use in Australian Society (pp. 223-246). South Melbourne: Oxford University Press.

McDonald, D., \& Hughes, C. (2017b). Chapter 11: Drug laws and regulations. In A. Ritter, T. King \& N. Lee (Eds.), Drug use in Australian society (2nd ed., pp. 223-246). South Melbourne: Oxford University Press.

Miller, C. L., Firestone, M., Ramos, R., Burris, S., Ramos, M. E., Case, P., . . Strathdee, S. A. (2008). Injecting drug users' experiences of policing practices in two Mexican-U.S. border cities: Public health perspectives. International Journal of Drug Policy, 19(4), 324-331. doi: https://doi.org/10.1016/j.drugpo.2007.06.002

Miller, P. G., \& Sønderlund, A. L. (2010). Using the internet to research hidden populations of illicit drug users: a review. Addiction, 105(9), 1557-1567. doi: 10.1111/j.1360-0443.2010.02992.x 
Mitchell, O., \& Caudy, M. S. (2015). Examining racial disparities in drug arrests. Justice Quarterly, 32(2), 288-313. doi: 10.1080/07418825.2012.761721

Morley, K. I., Lynskey, M. T., Moran, P., Borschmann, R., \& Winstock, A. R. (2015). Polysubstance use, mental health and high-risk behaviours: Results from the 2012 Global Drug Survey. Drug and alcohol review, 34(4), 427-437.

Organization of American States. (2013). Scenarios for the drug problem in the Americas 2013 2025. Washington D.C.: Organization of American States.

Pacula, R. L., Powell, D., Heaton, P., \& Sevigny, E. L. (2015). Assessing the effects of medical marijuana laws on marijuana use: The devil is in the details. Journal of Policy Analysis and Management, 34(1), 7-31. doi: 10.1002/pam.21804

Pratt, J., Brown, D., Brown, M., Hallsworth, S., \& Morrison, W. (2013). The new punitiveness. New York: Routledge.

Reuter, P. (2017). Creating a drug law enforcement research agenda. International Journal of Drug Policy, 41, 160-161. doi: 10.1016/j.drugpo.2017.01.005

Rhodes, T., Platt, L., Sarang, A., Vlasov, A., Mikhailova, L., \& Monaghan, G. (2006). Street policing, injecting drug use and harm reduction in a Russian city: A qualitative study of police perspectives. Journal of Urban Health, 83(5), 911-925. doi: 10.1007/s11524-006-9085-y

Ritter, A., Hughes, C., \& Hull, P. (2016a). Chapter 9: Drug policy. In T. Kolind, B. Thom \& G. Hunt (Eds.), The SAGE Handbook of Drug \& Alcohol Studies Volume 1 (pp. 135-163). London: Sage Publications.

Ritter, A., Livingston, M., Chalmers, J., Berends, L., \& Reuter, P. (2016b). Comparative policy analysis for alcohol and drugs: current state of the field. International Journal of Drug Policy, 31, 39-50.

Ritter, A., McLeod, R., \& Shanahan, M. (2013). Monograph No. 24: Government drug policy expenditure in Australia - 2009/10. DPMP Monograph Series. Sydney: National Drug and Alcohol Research Centre.

Ritter, A., \& Stevens, A. (2017). Improving knowledge on law enforcement in drug policy. International Journal of Drug Policy, 41, 89-90.

Rosmarin, A., \& Eastwood, N. (2013). A quiet revolution: Drug decriminalisation policies in practice across the globe. London: Release.

Ross, C. T. (2015). A Multi-Level Bayesian Analysis of Racial Bias in Police Shootings at the CountyLevel in the United States, 2011-2014. PLOS ONE, 10(11), e0141854. doi: 10.1371/journal.pone.0141854

Sarang, A., Rhodes, T., Sheon, N., \& Page, K. (2010). Policing drug users in Russia: Risk, fear, and structural violence. Substance Use \& Misuse, 45(6), 813-864. doi: $10.3109 / 10826081003590938$

Shanahan, M., Hughes, C., \& McSweeney, T. (2017). Australian police diversion for cannabis offences: Assessing program outcomes and cost-effectiveness Monograph No. 66. Canberra: National Drug Law Enforcement Research Fund.

Shanahan, M., Hughes, C. E., McSweeney, T., \& Griffin, B. A. (2017). Alternate policing strategies: Cost-effectiveness of cautioning for cannabis offences. International Journal of Drug Policy. doi: http://dx.doi.org/10.1016/j.drugpo.2016.12.012

Single, E., Christie, P., \& Ali, R. (1999). The impact of cannabis decriminalisation in Australia and the United States. Journal of Public Health Policy, 21(2), 157-186.

Stamatel, J. P. (2006). An overview of publicly available quantitative cross-national crime data. IASSIST Quarterly Winter, 16-20.

Stevens, A., \& Hughes, C. (2016). Dépénalisation et santé publique : politiques des drogues et toxicomanies au Portugal. Mouvements, 2(86), 22 - 33.

United Nations Office on Drugs and Crime. (2017a). UNODC Statistics. Vienna: United Nations Office on Drugs and Crime.

United Nations Office on Drugs and Crime. (2017b). World Drug Report 2017. Vienna: United Nations Office on Drugs and Crime.

Volkmann, T., Lozada, R., Anderson, C. M., Patterson, T. L., Vera, A., \& Strathdee, S. A. (2011). Factors associated with drug-related harms related to policing in Tijuana, Mexico. Harm Reduction Journal, 8(1), 7. doi: 10.1186/1477-7517-8-7

Wagenaar, A. C., \& Burris, S. C. (2013). Public health law research: theory and methods: John Wiley \& Sons.

Weatherburn, D. J. (2004). Law and order in Australia: Rhetoric and reality: Federation Press.

Winstock, A. R., Griffiths, P., \& Stewart, D. (2001). Drugs and the dance music scene: a survey of current drug use patterns among a sample of dance music enthusiasts in the UK. Drug and Alcohol Dependence, 64(1), 9-17. doi: http://dx.doi.org/10.1016/S0376-8716(00)00215-5 
Wood, E. F., Werb, D., Beletsky, L., Rangel, G., Cuevas Mota, J., Garfein, R. S., . . Wagner, K. D. (2017). Differential experiences of Mexican policing by people who inject drugs residing in Tijuana and San Diego. International Journal of Drug Policy, 41, 132-139. doi: 10.1016/j.drugpo.2016.12.010 
Figure 1: Predicted probability (and confidence bounds) of any recent drug policing encounter rank ordered by country (unadjusted for individual or country factors)

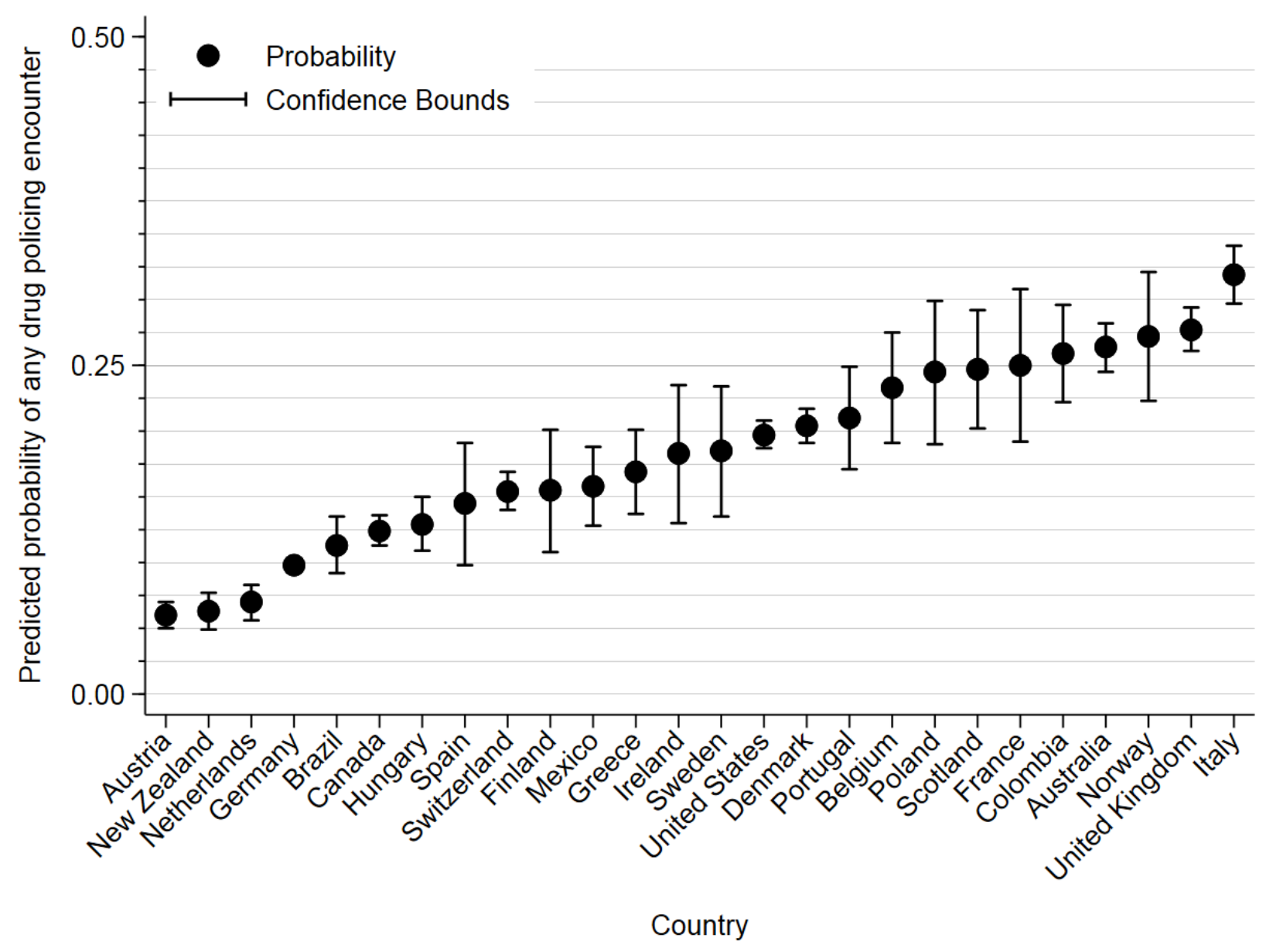


Figure 2: Predicted probability (and confidence bounds) of a drug policing encounter ending in arrest, by country (unadjusted for individual or national factors)

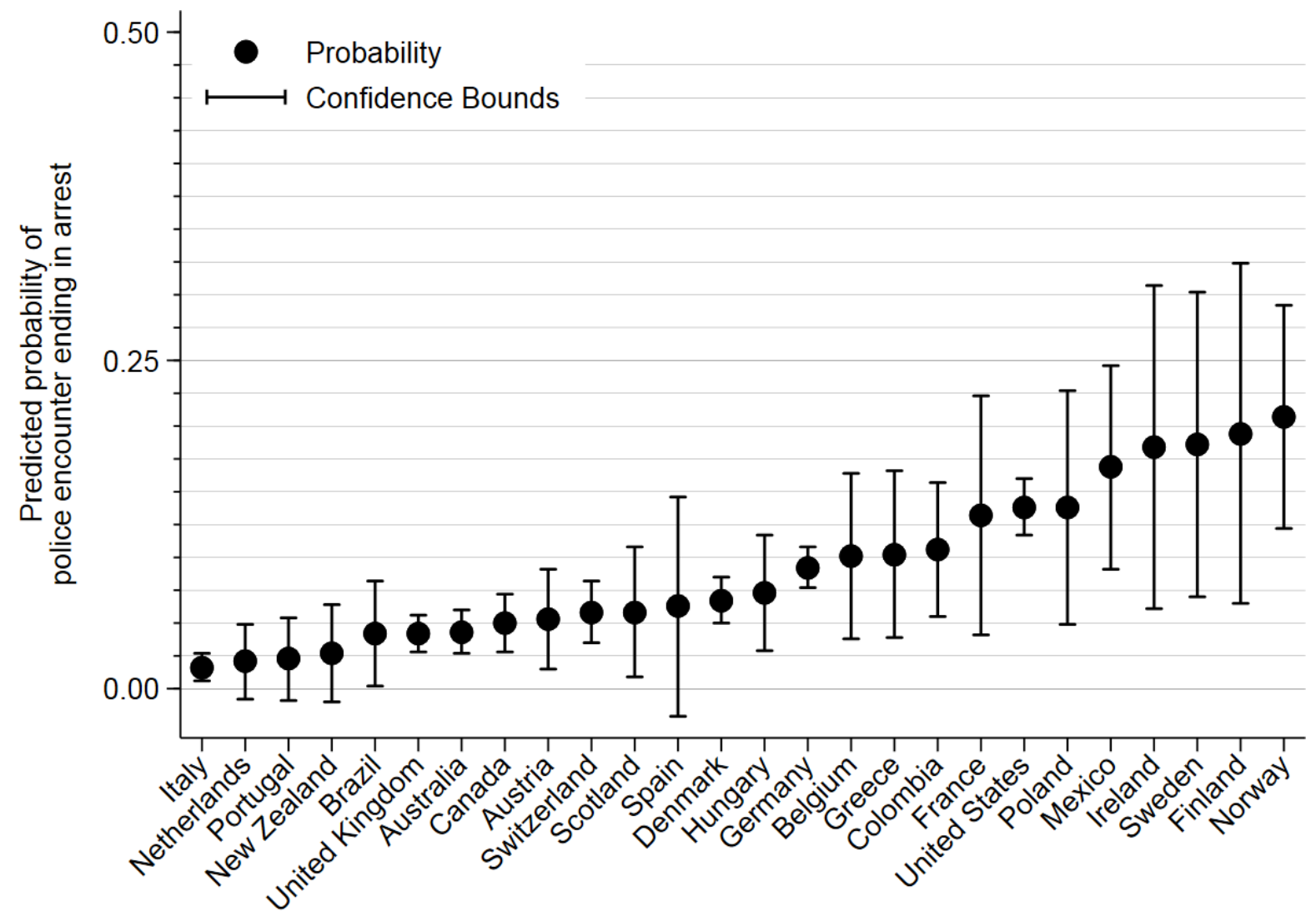

Country 
Figure 3: Probability (and confidence bounds) of any recent drug policing encounter, rank ordered by country, controlling for individual level and country level effects (as seen in Table 4 model 1c)

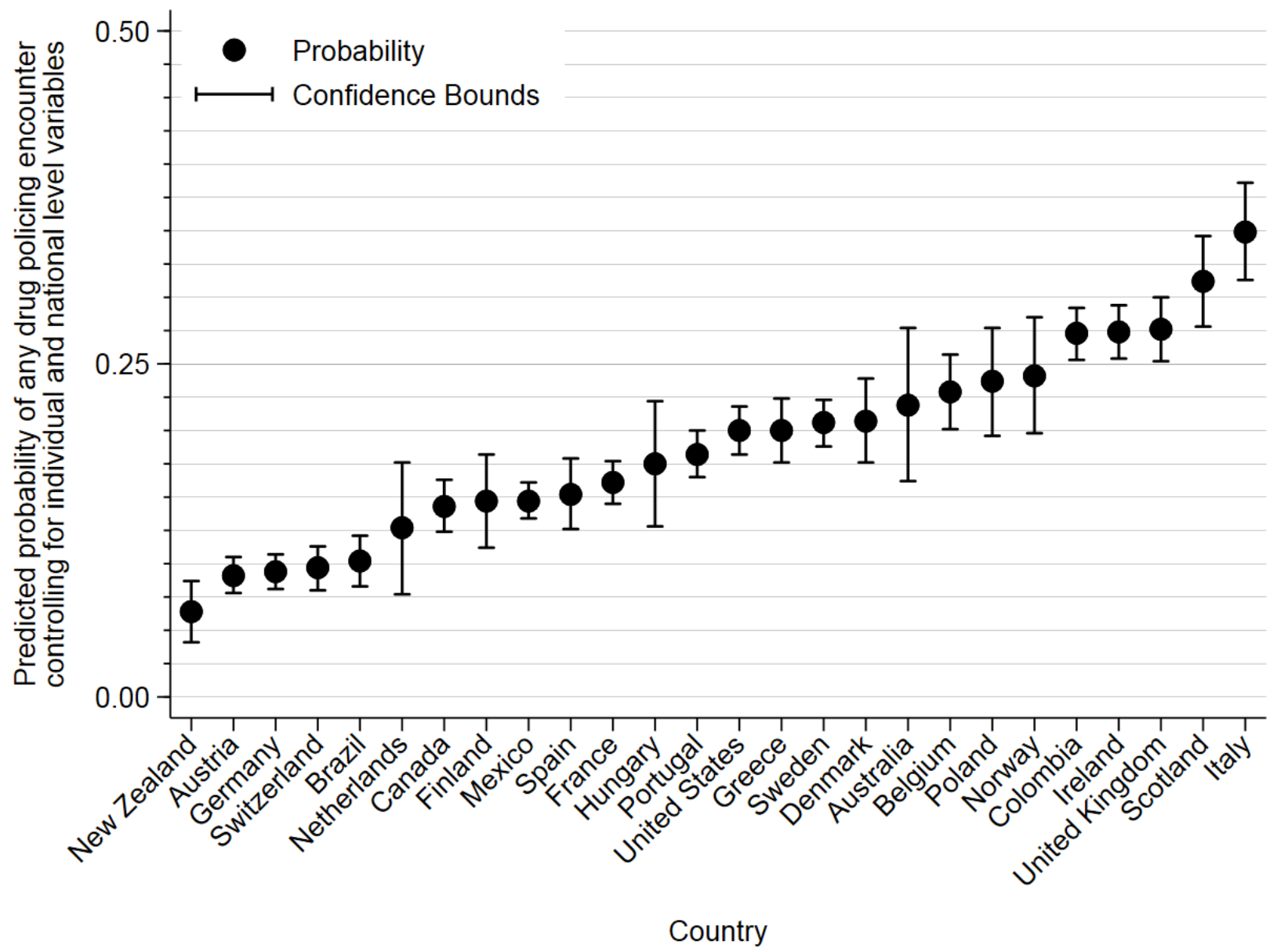


Figure 4a, 4b and 4c: Probability of a drug policing encounter by type - a) drug dog, b) stop and search and c) arrest, controlling for country and individual level variables, rank ordered by country

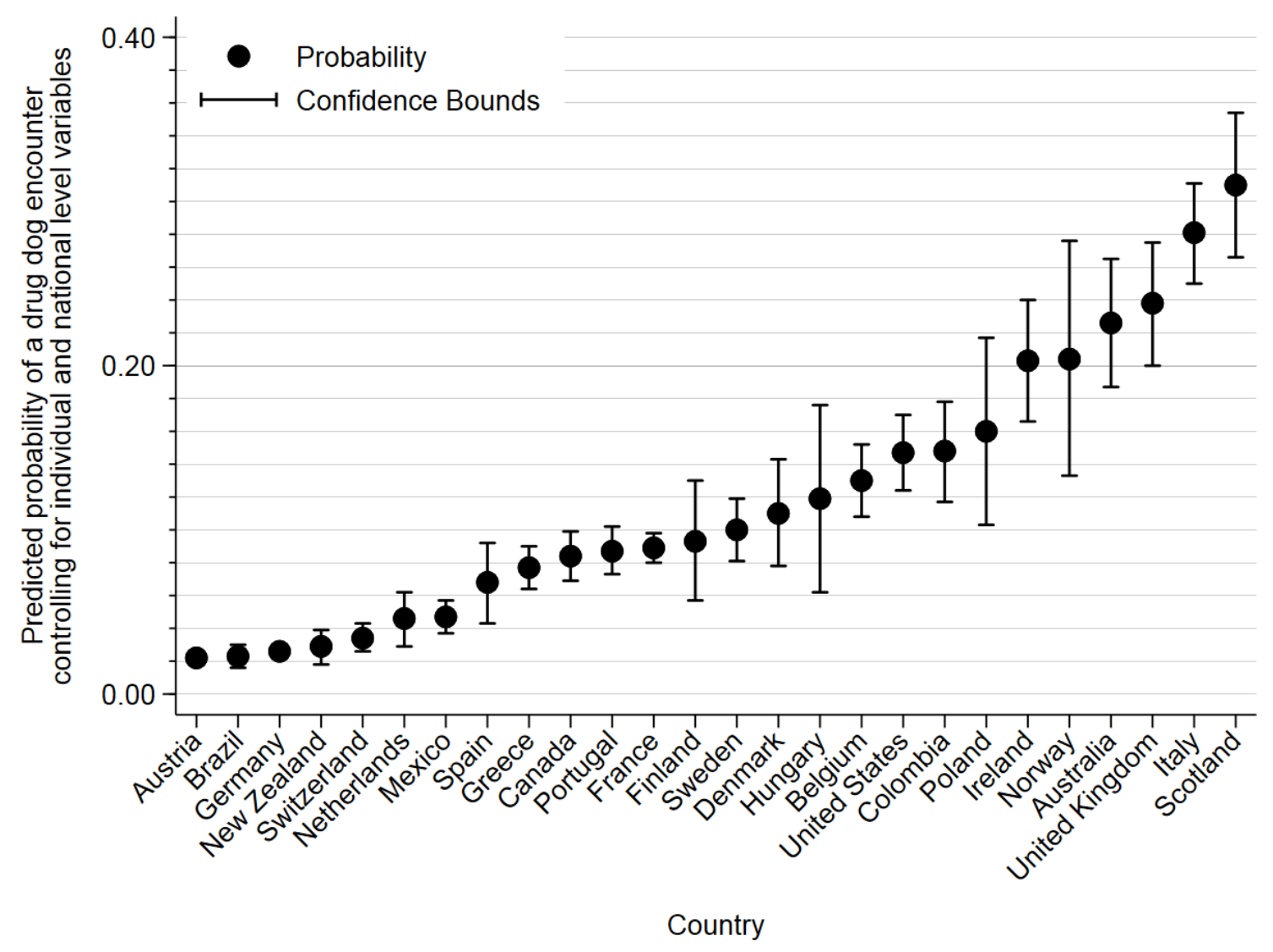




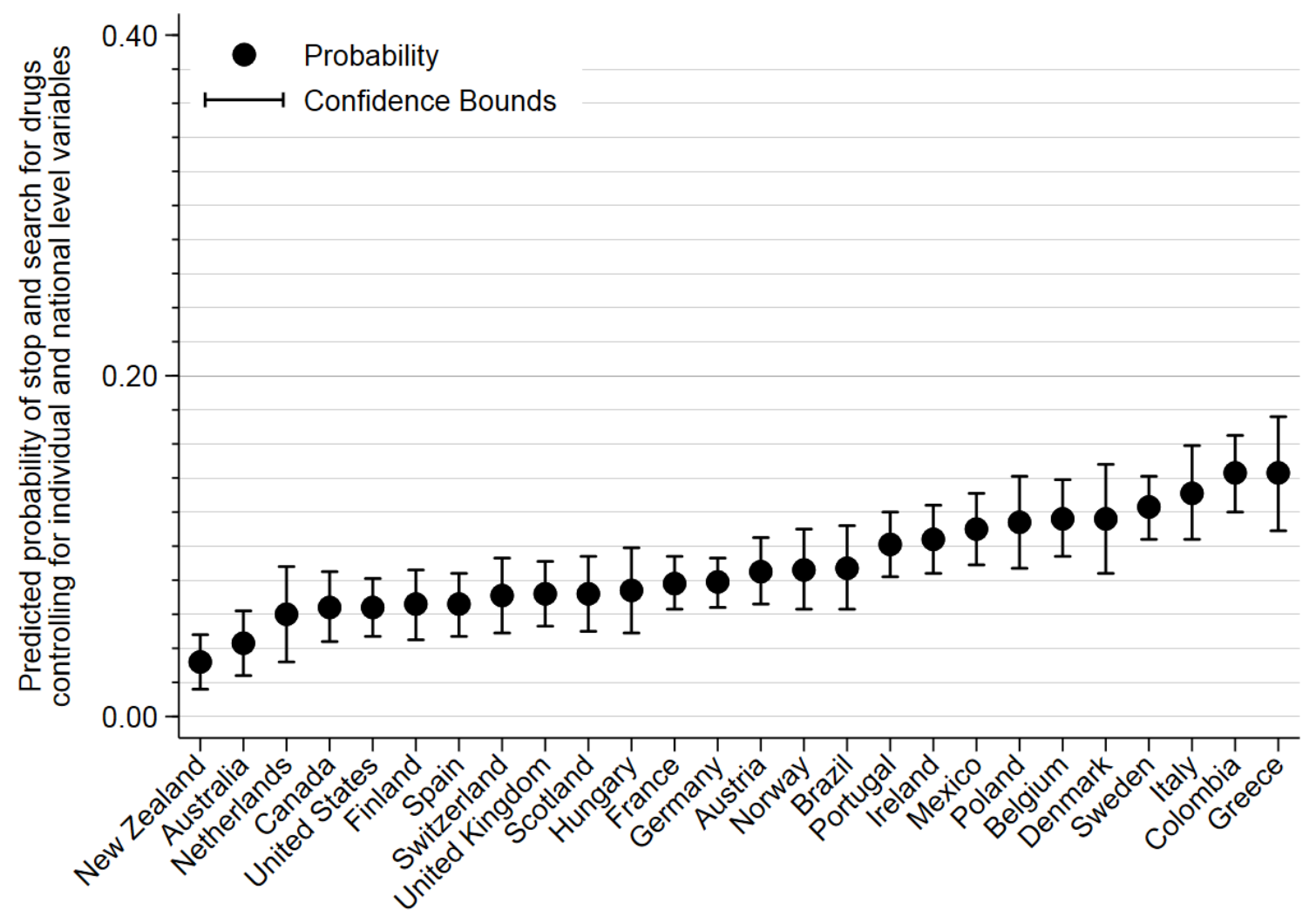

Country

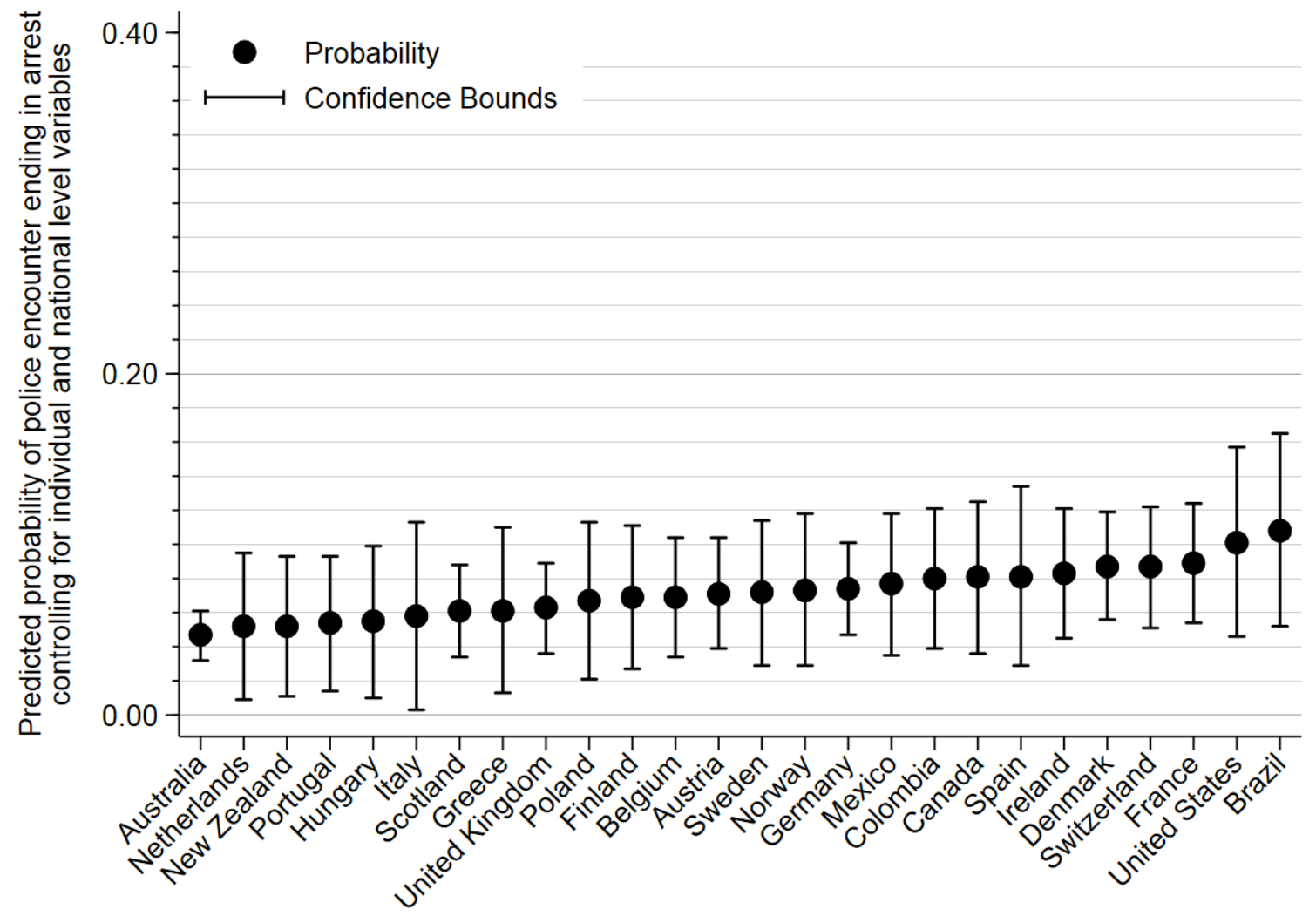

Country 
Table 1: GDS 2017 drug policing sample and country level factors, sourced from the UNODC and GDS

\begin{tabular}{|l|r|r|r|r|r|r|}
\hline Country & $\begin{array}{l}\text { Number of } \\
\text { respondents }\end{array}$ & $\begin{array}{l}\text { Prevalence } \\
\text { of cannabis } \\
\text { use in the } \\
\text { last 12 } \\
\text { months } \\
\text { amongst } \\
\text { the } \\
\text { population } \\
\text { aged 15-64 } \\
\text { (UNODC) }\end{array}$ & $\begin{array}{l}\text { Prevalence } \\
\text { of ecstasy } \\
\text { use in the } \\
\text { last 12 } \\
\text { months } \\
\text { amongst } \\
\text { the } \\
\text { population } \\
\text { aged 15-64 } \\
\text { (UNODC) }\end{array}$ & $\begin{array}{l}\text { Prevalence } \\
\text { of cocaine } \\
\text { use in the } \\
\text { last 12 } \\
\text { months } \\
\text { amongst } \\
\text { the } \\
\text { population } \\
\text { aged 15-64 } \\
\text { (UNODC) }\end{array}$ & $\begin{array}{l}\text { Aggregate } \\
\text { incidence of } \\
\text { police } \\
\text { encounters } \\
\text { in the last } \\
\text { 12 months } \\
\text { (GDS) }\end{array}$ & $\begin{array}{l}\text { Police } \\
\text { personnel } \\
\text { per 100,000 } \\
\text { population } \\
\text { (UNODC) }\end{array}$ \\
\hline Australia & 2,277 & 10.2 & 2.5 & 2.1 & $41.8 \%$ & 263.4 \\
\hline Austria & 2,196 & 6.4 & 0.4 & 0.4 & $22.8 \%$ & 327.3 \\
\hline Belgium & 382 & 4.6 & 0.9 & 0.5 & $37.3 \%$ & 345.4 \\
\hline Brazil & 840 & 2.5 & 0.2 & 1.0 & $18.9 \%$ & 262.4 \\
\hline Canada & 3,029 & 14.7 & 0.9 & 1.5 & $39.2 \%$ & 196.5 \\
\hline Colombia & 544 & 3.27 & 0.2 & 0.7 & $39.2 \%$ & 366.7 \\
\hline Denmark & 3,797 & 6.9 & 0.2 & 0.9 & $37.8 \%$ & 191.1 \\
\hline Finland & 233 & 6.8 & 1.1 & 0.5 & $39.2 \%$ & 140.8 \\
\hline France & 212 & 11.1 & 0.9 & 1.1 & $37.0 \%$ & 289.8 \\
\hline Germany & 13,629 & 6.1 & 0.6 & 0.6 & $23.2 \%$ & 304.1 \\
\hline Greece & 520 & 1.7 & 0.2 & 0.1 & $28.6 \%$ & 483.4 \\
\hline Hungary & 1,059 & 1.5 & 0.9 & 0.3 & $35.8 \%$ & 84.5 \\
\hline Ireland & 208 & 6 & 0.5 & 1.5 & $41.7 \%$ & 280.2 \\
\hline Italy & 1,710 & 9.2 & 0.4 & 1.1 & $48.5 \%$ & 462.6 \\
\hline Mexico & 564 & 1.2 & 0.1 & 0.5 & $25.4 \%$ & 367.0 \\
\hline Netherlands & 1,390 & 8 & 2.5 & 1.6 & $17.1 \%$ & 306.9 \\
\hline New Zealand & 1,177 & 11 & 2.0 & 0.6 & $28.9 \%$ & 196.7 \\
\hline Norway & 320 & 4.2 & 0.6 & 1.0 & $45.6 \%$ & 162.2 \\
\hline Poland & 237 & 4.6 & 0.3 & 0.2 & $44.9 \%$ & 253.1 \\
\hline Portugal & 414 & 2.7 & 0.3 & 0.2 & $34.9 \%$ & 438.2 \\
\hline Scotland & 348 & 6.3 & 1.7 & 2.3 & $41.0 \%$ & 224.6 \\
\hline Spain & 221 & 9.2 & 0.7 & 2.2 & $28.2 \%$ & 323.9 \\
\hline Sweden & 233 & 3.2 & 0.1 & 0.4 & $36.4 \%$ & 378.6 \\
\hline Switzerland & 2,444 & 8.1 & 0.3 & 0.6 & $29.6 \%$ & 206.8 \\
\hline United Kingdom & 2,839 & 6.5 & 1.5 & 2.3 & $38.2 \%$ & 219.4 \\
\hline United States & 5,119 & 16.5 & 1.2 & 2.3 & $44.5 \%$ & 220.0 \\
\hline
\end{tabular}


Table 2: Incidence of specific modes of drug policing (\%) - by type of policing and country $(n=45,942)$

\begin{tabular}{|l|r|r|r|r|r|r|}
\hline & $\begin{array}{l}\text { Drug dog } \\
\text { encounter }\end{array}$ & $\begin{array}{l}\text { Stop } \\
\text { and } \\
\text { search }\end{array}$ & Warning & Fine & \multicolumn{1}{l|}{$\begin{array}{l}\text { Offer of } \\
\text { bribe }\end{array}$} & Arrest \\
\hline Australia & 24.2 & 6.2 & 1.8 & 0.9 & 0.1 & 1.1 \\
\hline Austria & 1.7 & 4.0 & 2.0 & 0.7 & 0.2 & 0.3 \\
\hline Belgium & 16.8 & 13.6 & 7.3 & 2.9 & 0.3 & 2.4 \\
\hline Brazil & 1.5 & 9.9 & 3.0 & 1.2 & 1.1 & 0.5 \\
\hline Canada & 8.0 & 4.4 & 4.0 & 0.6 & 0.3 & 0.6 \\
\hline Colombia & 7.5 & 15.6 & 12.5 & 1.8 & 9.0 & 2.8 \\
\hline Denmark & 14.5 & 9.5 & 3.3 & 4.0 & 0.3 & 1.4 \\
\hline Finland & 10.7 & 4.3 & 2.6 & 4.3 & 0.0 & 3.0 \\
\hline France & 16.0 & 15.6 & 6.6 & 1.9 & 0.0 & 3.3 \\
\hline Germany & 2.3 & 8.4 & 2.5 & 1.2 & 0.1 & 0.9 \\
\hline Greece & 4.8 & 14.6 & 3.3 & 0.4 & 0.4 & 1.7 \\
\hline Hungary & 6.8 & 7.5 & 1.5 & 1.7 & 0.1 & 0.9 \\
\hline Ireland & 8.7 & 11.1 & 5.3 & 2.4 & 1.0 & 3.4 \\
\hline Italy & 27.3 & 10.8 & 2.7 & 0.9 & 0.1 & 0.5 \\
\hline Mexico & 6.6 & 7.6 & 6.7 & 2.0 & 7.4 & 2.7 \\
\hline Netherlands & 3.5 & 4.0 & 2.2 & 0.5 & 0.1 & 0.1 \\
\hline New Zealand & 4.1 & 1.4 & 1.4 & 0.0 & 0.3 & 0.2 \\
\hline Norway & 18.8 & 9.1 & 4.7 & 8.4 & 0.6 & 5.6 \\
\hline Poland & 10.1 & 17.3 & 4.2 & 1.7 & 0.4 & 3.4 \\
\hline Portugal & 11.1 & 14.7 & 5.8 & 1.2 & 0.0 & 0.5 \\
\hline Scotland & 25.1 & 7.8 & 3.4 & 0.9 & 0.0 & 1.4 \\
\hline Spain & 7.7 & 7.2 & 6.3 & 4.5 & 0.5 & 0.9 \\
\hline Sweden & 9.0 & 1.7 & 3.9 & 0.0 & 3.4 \\
\hline Switzerland & 6.3 & 2.9 & 5.0 & 5.8 & 0.2 & 0.9 \\
\hline United Kingdom & 8.0 & 3.3 & 1.7 & 0.4 & 1.2 \\
\hline United States & & & & & 0.2 & 1.2 \\
\hline Average & 12.9 & 4.9 & 2.3 & 0.1 & 2.7 \\
\hline
\end{tabular}


Table 3: Incidence of drug dog encounters (\%) by location and country (multiple locations could be reported) $(n=4,307)$

\begin{tabular}{|c|c|c|c|c|c|}
\hline Country & Festival & $\begin{array}{l}\text { Pub or } \\
\text { club }\end{array}$ & $\begin{array}{l}\text { Public } \\
\text { transport }\end{array}$ & Residential & Other \\
\hline Australia & 69.9 & 35.9 & 55.6 & 0.9 & 6.9 \\
\hline Austria & 40.5 & 13.5 & 32.4 & 0.0 & 10.8 \\
\hline Belgium & 73.4 & 12.5 & 39.1 & 0.0 & 4.7 \\
\hline Brazil & 38.5 & 23.1 & 23.1 & 7.7 & 15.4 \\
\hline Canada & 49.0 & 7.9 & 43.6 & 2.9 & 20.7 \\
\hline Colombia & 53.7 & 2.4 & 24.4 & 2.4 & 29.3 \\
\hline Denmark & 65.8 & 11.3 & 31.3 & 5.8 & 17.3 \\
\hline Finland & 60.0 & 12.0 & 36.0 & 12.0 & 16.0 \\
\hline France & 61.8 & 5.9 & 32.4 & 2.9 & 8.8 \\
\hline Germany & 55.2 & 2.9 & 35.1 & 2.6 & 7.8 \\
\hline Greece & 4.0 & 0.0 & 44.0 & 4.0 & 32.0 \\
\hline Hungary & 81.9 & 6.9 & 12.5 & 1.4 & 5.6 \\
\hline Ireland & 66.7 & 0.0 & 44.4 & 5.6 & 11.1 \\
\hline Italy & 49.9 & 9.9 & 58.0 & 0.9 & 13.9 \\
\hline Mexico & 35.1 & 8.1 & 37.8 & 0.0 & 8.1 \\
\hline Netherlands & 79.6 & 10.2 & 24.5 & 2.0 & 6.1 \\
\hline New Zealand & 35.4 & 2.1 & 27.1 & 4.2 & 35.4 \\
\hline Norway & 51.7 & 10.0 & 35.0 & 16.7 & 11.7 \\
\hline Poland & 54.2 & 4.2 & 66.7 & 8.3 & 8.3 \\
\hline Portugal & 65.2 & 10.9 & 23.9 & 2.2 & 13.0 \\
\hline Scotland & 65.7 & 28.6 & 30.0 & 1.4 & 7.1 \\
\hline Spain & 47.1 & 11.8 & 52.9 & 0.0 & 11.8 \\
\hline Sweden & 39.3 & 3.6 & 46.4 & 0.0 & 17.9 \\
\hline Switzerland & 28.3 & 4.0 & 46.5 & 1.0 & 19.2 \\
\hline United Kingdom & 72.8 & 34.0 & 35.3 & 0.6 & 5.7 \\
\hline United States & 45.8 & 10.2 & 45.5 & 6.5 & 19.1 \\
\hline Average & 58.7 & 16.8 & 41.6 & 3.0 & 12.8 \\
\hline
\end{tabular}


Table 4: Multilevel regression predicting the probability of a drug policing encounter in the last 12 months - controlling for a) random intercepts only, b) individual level factors; and c) individual and country level factors

\begin{tabular}{|c|c|c|c|c|c|c|}
\hline & \multicolumn{2}{|c|}{ Model 1a } & \multicolumn{2}{|c|}{ Model 1b } & \multicolumn{2}{|c|}{ Model 1c } \\
\hline & OR & $\mathbf{C l}$ & OR & $\mathbf{C l}$ & OR & $\mathbf{C l}$ \\
\hline Constant & $0.187^{\star \star \star}$ & $\begin{array}{l}0.133- \\
0.264\end{array}$ & 1.184 & $\begin{array}{l}0.635- \\
2.206\end{array}$ & $0.097^{\star \star \star}$ & $\begin{array}{l}0.042- \\
0.220\end{array}$ \\
\hline \multicolumn{7}{|l|}{ Individual level factors } \\
\hline \multicolumn{7}{|l|}{ Sex } \\
\hline - $\quad$ Male vs female & & & $1.584^{* \star *}$ & $\begin{array}{l}1-256- \\
1.996\end{array}$ & $1.565^{\star \star \star}$ & $\begin{array}{l}1.202- \\
2.038\end{array}$ \\
\hline - $\quad$ Transgender vs female & & & 0.859 & $\begin{array}{l}0.492- \\
1.497\end{array}$ & 0.761 & $\begin{array}{l}0.411- \\
1.409\end{array}$ \\
\hline Age & & & $0.880^{* * *}$ & $\begin{array}{l}0.841- \\
0.921\end{array}$ & $0.897^{\star \star \star}$ & $\begin{array}{l}0.865- \\
0.930\end{array}$ \\
\hline $\mathrm{Age}^{2}$ & & & $1.001^{* \star *}$ & $\begin{array}{l}1.000- \\
1.002\end{array}$ & $1.000^{* \star *}$ & $\begin{array}{l}1.000- \\
1.001 \\
\end{array}$ \\
\hline \multicolumn{7}{|l|}{ Residence } \\
\hline - $\quad$ Regional vs metropolitan & & & 1.169 * & $\begin{array}{l}1.024- \\
1.335\end{array}$ & $1.153^{*}$ & $\begin{array}{l}1.015- \\
1.311\end{array}$ \\
\hline - Remote vs metropolitan & & & 1.168 & $\begin{array}{l}0.913- \\
1.493\end{array}$ & 1.038 & $\begin{array}{l}0.903- \\
1.192\end{array}$ \\
\hline $\begin{array}{l}\text { Ethnicity: White/Caucasian vs } \\
\text { other }\end{array}$ & & & $0.751^{\star *}$ & $\begin{array}{l}0.612- \\
0.920\end{array}$ & $0.860^{* \star \star}$ & $\begin{array}{l}0.784- \\
0.943\end{array}$ \\
\hline \multicolumn{7}{|l|}{ Employment status } \\
\hline $\begin{array}{l}\text { - Paid employment versus } \\
\text { unemployed and not } \\
\text { looking for work }\end{array}$ & & & $1.342^{* * *}$ & $\begin{array}{l}1.194- \\
1.508\end{array}$ & $1.258^{* \star *}$ & $\begin{array}{l}1.160- \\
1.365\end{array}$ \\
\hline $\begin{array}{l}\text { Unemployed (looking for } \\
\text { work) versus unemployed } \\
\text { and not looking for work }\end{array}$ & & & $1.807^{* * *}$ & $\begin{array}{l}1.481- \\
2020\end{array}$ & $1.621^{\star * *}$ & $\begin{array}{l}1.409- \\
1.867\end{array}$ \\
\hline \multicolumn{7}{|l|}{ Clubbing frequency } \\
\hline $\begin{array}{ll}-\quad<4 \text { times per year versus } \\
\text { never }\end{array}$ & & & 1.171 & $\begin{array}{l}0.945- \\
1.450\end{array}$ & $1.389^{* \star \star}$ & $\begin{array}{l}1.205- \\
1.504\end{array}$ \\
\hline $\begin{array}{l}\text { - } 4 \text { or more times per year } \\
\text { versus never }\end{array}$ & & & $1.308^{*}$ & $\begin{array}{l}1.040- \\
1.645\end{array}$ & $1.674^{\star \star \star}$ & \\
\hline $\begin{array}{l}\text { Any prior police encounters: yes vs } \\
\text { no }\end{array}$ & & & 1.038 ** & $\begin{array}{l}1.024- \\
1.335\end{array}$ & 1.031 ** & $\begin{array}{l}1.010- \\
1.051\end{array}$ \\
\hline \multicolumn{7}{|l|}{ Country level factors } \\
\hline $\begin{array}{l}\text { - Prevalence of cannabis } \\
\text { use }\end{array}$ & & & & & $0.952^{* \star \star}$ & $\begin{array}{l}0.9311- \\
0.974\end{array}$ \\
\hline $\begin{array}{l}\text { - Prevalence of ecstasy } \\
\text { use }\end{array}$ & & & & & 1.112 & $\begin{array}{l}0.879- \\
1.408 \\
\end{array}$ \\
\hline $\begin{array}{ll}\text { - } & \begin{array}{l}\text { Prevalence of cocaine } \\
\text { use }\end{array} \\
\end{array}$ & & & & & $1.357^{\star \star *}$ & $\begin{array}{l}1.158- \\
1.591 \\
\end{array}$ \\
\hline $\begin{array}{l}\text { - Total no. police personnel } \\
\text { per } 100,000 \text { pop }\end{array}$ & & & & & 1.001 ** & $\begin{array}{l}1.000- \\
1.002\end{array}$ \\
\hline $\begin{array}{l}\text { - Aggregate rate any police } \\
\text { encounters }\end{array}$ & & & & & $1.046^{* \star *}$ & $\begin{array}{l}1.033- \\
1.059\end{array}$ \\
\hline
\end{tabular}

${ }^{*} p<0.05,{ }^{\star *} p<0.01,{ }^{\star \star *} p<0.001$. Model 1a: $r 2=0.000$. Model 1b: $r 2=0.091 . X^{2}(15)=557.23 . p<0.001$. Model $1 c: r 2=0.114 . X^{2}(17)$ $=5626.73 . p<0.001$. 


\section{Supplementary Material}

Table S1: Demographics and drug use characteristics of GDS drug policing sample $(n=45,942)$

\begin{tabular}{|c|c|}
\hline & $\begin{array}{l}\text { Drug Policing } \\
\text { Sub-sample }\end{array}$ \\
\hline \multicolumn{2}{|l|}{ Demographics } \\
\hline \multicolumn{2}{|l|}{ Age } \\
\hline - $\quad$ Mean (SD) & $28.55(\mathrm{SD}=10.51)$ \\
\hline - $\quad$ Range & $18-80$ \\
\hline \multicolumn{2}{|l|}{ Sex } \\
\hline - Male & $71.9 \%$ \\
\hline - $\quad$ Female & $27.6 \%$ \\
\hline - Transgender & $0.5 \%$ \\
\hline \multicolumn{2}{|l|}{ Sexual orientation } \\
\hline - Heterosexual & $81.4 \%$ \\
\hline - $\quad$ GLBTI & $16.4 \%$ \\
\hline - $\quad$ Prefer not to answer & $2.2 \%$ \\
\hline \multicolumn{2}{|l|}{ Ethnicity } \\
\hline - White/Caucasian & $89.4 \%$ \\
\hline - Hispanic/Latino & $3.4 \%$ \\
\hline - $\quad$ Mixed & $3.6 \%$ \\
\hline - $\quad$ Other & $3.6 \%$ \\
\hline \multicolumn{2}{|l|}{ Residence } \\
\hline - $\quad$ City/urban & $73.3 \%$ \\
\hline - Regional & $23.0 \%$ \\
\hline - Rural & $3.7 \%$ \\
\hline \multicolumn{2}{|l|}{ Education - highest qualification attained } \\
\hline - Degree or higher & $36.9 \%$ \\
\hline - College certificate / diploma & $24.9 \%$ \\
\hline - Higher secondary school / HSC & $19.0 \%$ \\
\hline - Other & $19.2 \%$ \\
\hline \multicolumn{2}{|l|}{ Employment } \\
\hline - Full time employment & $42.7 \%$ \\
\hline - $\quad$ Part time employment & $20.7 \%$ \\
\hline - $\quad$ Non-working student & $24.3 \%$ \\
\hline - Unemployed: looking for work & $7.0 \%$ \\
\hline - Unemployed: other & $5.3 \%$ \\
\hline \multicolumn{2}{|l|}{ Illicit drug use and clubbing } \\
\hline \multicolumn{2}{|c|}{ Prevalence of illicit drug use in the last 12 months } \\
\hline - Cannabis & $91.3 \%$ \\
\hline - Ecstasy & $37.5 \%$ \\
\hline - Cocaine & $30.3 \%$ \\
\hline - $\quad$ Amphetamine & $19.7 \%$ \\
\hline - LSD & $18.7 \%$ \\
\hline - $\quad$ Magic mushrooms & $17.6 \%$ \\
\hline - $\quad$ Any NPS & $16.6 \%$ \\
\hline \multicolumn{2}{|l|}{ Clubbing frequency } \\
\hline - 4 or more times per year & $55.9 \%$ \\
\hline - Less than 4 times per year & $22.4 \%$ \\
\hline - No clubbing & $21.6 \%$ \\
\hline
\end{tabular}


Figure S1: The relationship between UNODC country level variables - number of police personnel per 100,000 population and prevalence of recent drug use, by country

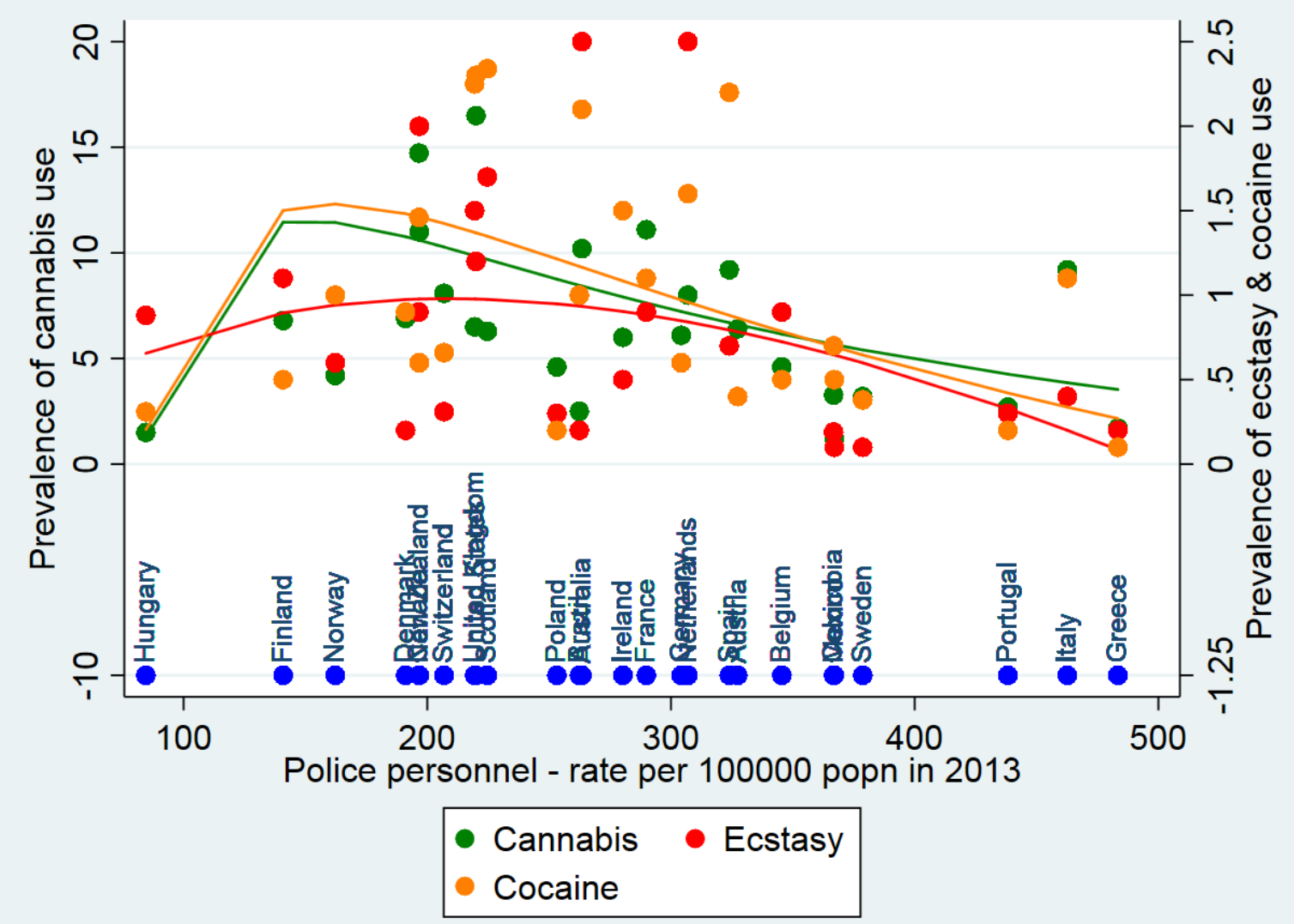

